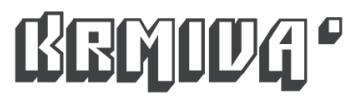

HRANIDBENA VRIJEDNOST FERMENTIRANE KRME DVAJU HIBRIDA SUDANSKE TRAVE

\section{THE FEEDING VALUE OF TWO ENSILED SUDAN GRASS HYBRIDS}

\author{
Marina Vranić, K. Bošnjak, Jasna Lehunšek, R. Gantner, K. Krapinec, Marcela
} Andreata-Koren

Izvorni znanstveni članak - Original scientific paper

Primljeno - Received: 10. prosinac - December 2020

\section{SAŽETAK}

Cilj rada bio je usporediti proizvodnost i hranidbenu vrijednost fermentirane krme dvaju hibrida sudanske trave s obzirom na prinos krme po jedinici površine te osnovni kemijski sastav i kvalitetu fermentacije krme u silosu. $U$ istraživanju su korištene dvije sorte sudanske trave, sorta Su-Su i sorta Pacific graze. Istraživanje je provedeno tijekom vegetacijske sezone 2014. godine na pokusnoj površini pokušališta Maksimir Agronomskog fakulteta Sveučilišta u Zagrebu

Pokošena biljna masa je silirana u laboratorijske silose. Nakon 35 dana od zatvaranja silosa, fermentirana krma je analizirana NIR spektroskopijom na osnovni kemijski sastav i kvalitetu fermentacije, procjenom sadržaja organske tvari (OT), sirovih proteina (SP), neutralnih detergent vlakana (NDV), kiselih detergent vlakana $(\mathrm{KDV})$, metaboličke energije (ME), probavljivosti organske tvari u suhoj tvari (D-vrijednost), razgradivosti sirovih proteina (RSP), faktora konzumacije za ovce i goveda, $\mathrm{pH}$ vrijednosti i amonijskog $\mathrm{N}\left(\mathrm{NH}_{3}-\mathrm{N}\right)$. Nisu utvrđene statistički značajne razlike između hibrida Pacific graze i Su-su u istraživanim parametrima. Prinos ST hibrida Pacific graze i Su-su je iznosio 11,5 $\mathrm{t} \mathrm{ha}^{-1}$ i $12,88 \mathrm{t} \mathrm{ha}^{-1}$ tim slijedom $(\mathrm{P}>0,409)$, sadržaj SP 102,3 $\mathrm{g} \mathrm{kg}^{-1}$ ST i 103,8 $\mathrm{g} \mathrm{kg}^{-1}$ ST tim slijedom (P>0,802), sadržaj NDV $507 \mathrm{~g} \mathrm{~kg}^{-1}$ ST i $514 \mathrm{~g} \mathrm{~kg}^{-1}$ ST tim slijedom(P>0.523), D-vrijednost $605 \mathrm{~g} \mathrm{~kg}^{-1}$ ST i $602 \mathrm{~g} \mathrm{~kg}^{-1}$ ST tim slijedom ( $P>0,341$ ), pH vrijednost 4,26 i 4,4 tim slijedom (P>0,193), a sadržaj $\mathrm{NH}_{3}-\mathrm{N} 116 \mathrm{~g} \mathrm{NH}_{3} \mathrm{~kg}^{-1}$ ukupnog $\mathrm{N}$ i $131 \mathrm{~g} \mathrm{NH}_{3} \mathrm{~kg}^{-1}$ ukupnog $\mathrm{N}$ tim slijedom $(\mathrm{P}>0,254)$. Zaključeno je da oba hibrida sudanske trave imaju potencijal za proizvodnju fermentirane voluminozne krme visokog prinosa po jedinici površine, a niža hranidbena vrijednost fermentirane krme utvrđena u ovom istraživanju je rezultat kasnijeg roka košnje biljne mase za siliranje. tacije

Ključne riječi: sudanska trava, sorta, hranidbena vrijednost, kvaliteta fermen-

\footnotetext{
Marina Vranić, Krešimir Bošnjak, e-mail: kbosnjak@agr.hr, Agronomski fakultet Sveučilišta u Zagrebu, Zavod za specijalnu proizvodnju bilja, Svetošimunska cesta 25, 10000 Zagreb, Hrvatska; Jasna Lehunšek, studentica Agronomskog fakulteta Sveučilišta u Zagrebu; Ranko Gantner, Sveučilište Josipa Jurja Strossmayera u Osijeku, Fakultet agrobiotehničkih znanosti Osijek, Vladimira Preloga 1, 31000 Osijek. Hrvatska; Krešimir Krapinec, Šumarski fakultet Sveučilišta u Zagrebu, Zavod za zaštitu šuma i lovno gospodarenje, Svetošimunska 25, 10000 Zagreb, Hrvatska; Marcela Andreata-Koren, Visoko gospodarsko učilište u Križevcima, Milislava Demerca 1 , 48260 Križevci, Hrvatska
} 


\section{UVOD}

Sudanska trava (Sorghum vulgare var. sudanense) je jednogodišnja termofilna jara biljna vrsta koja pripada porodici trava (Poaceae), potporodici Panicoidae i rodu Sorghum. Hranidbena vrijednost krmiva uključuje palatabilnost krmiva, konzumaciju, probavljivost (Cleale i Bull, 1986.), sadržaj ili koncentraciju hranjivih tvari (Niderkorn i Baumont, 2009.), a za fermentiranu krmu i koncentraciju produkata fermentacije u silosu (Chamberlain i Wilkinson, 1996.).

Sudanska trava daje visoke prinose biljne mase po jedinici površine (McLaren i sur. 2003.) i otporna je na sušne uvjete uzgoja, pa je odlična nadopuna višegodišnjim krmnim travama koje imaju nizak prinos biljne mase tijekom ljetnih mjeseci (Stjepanović i sur., 2011.). Sudanska trava i hibridi sudanske trave se koriste u hranidbi životinja, najčešće kao svježa ili silirana voluminozna krma, a rjeđe kao sijeno ili paša (Erić i sur., 1999.; Stjepanović i sur., 2011.). Može se koristiti i kao sirovina za proizvodnju biljnog brašna (Stjepanović i sur., 2011.), ali u posljednje vrijeme se sve više koristi za proizvodnju bioplina i biodizela, etanola i drugih industrijskih proizvoda poput bioplastičnih masa (McLaren i sur., 2003.) zbog visokog prinosa biomase po jedinici površine (Kralik i sur., 2009.; Uzun i sur., 2009.; Stipešević i sur., 2019.) i visoke energetske vrijednosti suhe tvari (ST) proizvedene krme (Parlak i sur., 2016.; Stipešević i sur., 2019.). Sudanska trava može osigurati 2-4 otkosa biljne mase tijekom vegetacijske sezone, visoke je probavljivosti i ad libitum konzumacije krme (Kralik i sur., 2009.).

Primijenjena agrotehnologija uzgoja, od gnojidbe usjeva i razine obrade tla za sjetvu (Stipešević i sur., 2019.) do odabira sorte (Miron i sur., 2006.; Uzun i sur., 2009.; Budak i Aydemir, 2017.) i roka košnje biljne mase (Afzal i sur., 2012.; Parlak i sur., 2016.), utječe na prinos i hranidbenu vrijednost sudanske trave.

Prinos zelene biljne mase različitih hibrida sudanske trave može varirati od 40-50 t svježe biljne mase ha ${ }^{-1}$ (Kralik i sur., 2009.) do $97 \mathrm{t}$ svježe biljne mase ha ${ }^{-1}$ (Uzun i sur., 2009.). Prinos kvalitetnog sijena sudanske trave može iznositi 9-12 t ha ${ }^{-1}$ (Kralik i sur., 2009.).

Sudansku travu je najbolje kositi na visini od 10$12 \mathrm{~cm}$ od razine tla, da se ne oštete prizemni članci iz kojih izbijaju sekundarni izboji, čime je omogućena brža regeneracija krme narednog otkosa (Stjepanović i sur., 2011.).
Košnja sudanske trave u ranijim fazama fenološke zrelosti daje krmu veće hranidbene vrijednosti, a u kasnijim fazama zrelosti daje veći prinos krme (Ibrahim i sur., 2016.). Sudanska trava košena u fazi početka metličanja može sadržavati $148 \mathrm{~g} \mathrm{SP} \mathrm{kg}^{-1}$ ST i $242 \mathrm{~g} \mathrm{SV} \mathrm{kg}^{-1}$ ST (Stjepanović i sur., 2011.). Neto energetska vrijednost laktacije (NEL) kilograma ST sudanske trave je oko 6,15 MJ što je slično NEL kilograma ST cijele biljke kukuruza u fazi kasne voštane zriobe zrna (Stjepanović i sur., 2011.).

Hipoteza istraživanja je bila da će sorta sudanske trave utjecati na prinos krme sudanske trave po jedinici površine, na hranidbenu vrijednost fermentirane krme i kvalitetu fermentacije u silosu. Cilj istraživanja bio je usporediti prinos krme po jedinici površine i hranidbenu vrijednost dvaju hibrida sudanske trave obzirom na osnovni kemijski sastav $i$ kvalitetu fermentacije u silosu.

\section{MATERIJAL I METODE RADA}

\section{Postavljanje i provedba istraživanja}

Istraživanje je provedeno tijekom vegetacijske sezone 2014. godine na pokusnoj parceli pokušališta Maksimir Agronomskog fakulteta Sveučilišta u Zagrebu.

Osnovna obrada tla izvršena je u veljači 2014. godine oranjem tla na dubinu od $30 \mathrm{~cm}$. Predsjetvena obrada tla obavljena je roto-drljačom, neposredno prije sjetve. Sjetva je izvršena 18.5.2014. godine žitnom sijačicom na dubinu od $4 \mathrm{~cm}$ s međurednim razmakom od $22 \mathrm{~cm}$. Sjetvena norma je iznosila 30 $\mathrm{kg} \mathrm{ha}^{-1}$ svakog od dva hibrida sudanske trave (SuSu i Pacific graze). Za obje je sorte posijana površina od $1500 \mathrm{~m}^{2}\left(750 \mathrm{~m}^{2}\right.$ za svaku sortu). Osnovna gnojidba je iznosila $250 \mathrm{~kg}^{\text {ha-1 }}$ NPK gnojiva formulacije 15-15-15 ha-1. Pokus je postavljen po potpuno slučajnom rasporedu sa 6 ponavljanja za svaku sortu. Ukupno su tijekom 2014. godine skinuta dva otkosa krme sudanske trave.

\section{Utvrđivanje prinosa krme \\ i formiranje laboratorijskih silosa}

Uzorci prvog otkosa sudanske trave za potrebe istraživanja uzeti su pri prosječnoj visini biljke sudanske trave od $110 \mathrm{~cm}$ u fazi početka metličanja. Biljna masa je ručnim škarama rezana na visini od 
$12 \mathrm{~cm}$ od razine tla na 6 potpuno slučajno odabranih mjesta po tretmanu. Svako mjesto uzorkovanja bilo je površine $0,22 \mathrm{~m}^{2}(1 \mathrm{~m} \times 0,22 \mathrm{~m})$. Uzeta biljna masa je odvojeno izvagana radi utvrđivanja prinosa krme. Od svake sorte sudanske trave uzeti su uzorci biljne mase za utvrđivanje sadržaja ST i pH biljne mase prije siliranja.

Uzorak svježe biljne mase svake sorte (cca $7 \mathrm{~kg}$ ) je sasjeckan na prosječnu duljinu od 3-4 cm korištenjem električne sjeckalice. Sasjeckana biljna masa je silirana u laboratorijske silose, koristeći vakuum uređaj (Smart-Vac) i njemu pripadajuće čvrste PVC role iz kojih su formirani laboratorijski silosi. Od svake sorte sudanske trave formirano je po 6 laboratorijskih silosa, pa je ukupno formirano 12 laboratorijskih silosa, svaki cca $350 \mathrm{~g}$ biljne mase. Nakon 35 dana od zatvaranja silosa, silosi su otvoreni radi utvrđivanja hranidbene vrijednosti fermentirane biljne mase.

\section{Kemijske analize}

Vrijednost $\mathrm{pH}$ je utvrđivana u filtratu dobivenom od cca 10 grama svježe silaže i $100 \mathrm{ml}$ destilirane vode korištenjem pH metra (WTE, model 315i). Sadržaj ST je utvrđen sušenjem uzoraka u sušioniku s ventilatorom (EAS23-030) na temperaturi od $60^{\circ} \mathrm{C}$ do konstante mase poduzorka (AOAC, 1990). Uzorci su samljeveni u mlinu čekićaru (ChristyNoris) kroz sito otvora $1 \mathrm{~mm}$, dosušivani 3 sata u sušioniku na temperaturi od $105^{\circ} \mathrm{C}$ i skenirani na NIRS aparatu (Foss, model 6500) pomoću infracrvenog elektromagnetskog spektra valne duljine 1100-2500 nm, u intervalima po $2 \mathrm{~nm}$. Spektrima uzoraka pridružene su odgovarajuće kalibracije (Vranić i sur, 2019.b). $\mathrm{U}$ odnosu na ranije utvrđen sadržaj ST, procijenjeni su (i) kemijski parametri hranidbene vrijednosti: korigirana suha tvar (ST), sirovi proteini (SP), neutralna detergent vlakna (NDV), metabolička energija (ME), (ii) parametri kvalitete fermentacije u silosu: fermentirajuća ME u ME (FME/ME), amonijski dušik $\left(\mathrm{NH}_{3}-\mathrm{N}\right)$, rezidui šećera i (iii) biološki parametri hranidbene vrijednosti fermentirane krme: probavljivost organske tvari u suhoj tvari (D-vrijednost) i razgradivost SP u buragu. Kalibracijski modeli za procjenu kemijskih i bioloških parametara NIR spektroskopijom su razvijani provedbom klasičnih kemijskih analiza i in vivo istraživanja kako je ranije opisano (Vranić i sur., 2019.a, 2019.b, 2020.). Faktor konzumacije krme za goveda i za ovce je procjenjivan NIR spektroskopijom korištenjem razvijenih kalibra- cijskih modela kod kojih faktor konzumacije 100 govori o krmi prosječne preferencije za pojedinu vrstu životinja. Kalibracijski modeli za procjenu bioloških parametara hranidbene vrijednosti fermentirane krme razvijani su 20-ak godina u Scottish Agricultural College (SAC).

\section{Statističke analize}

Rezultati su obrađeni u statističkom programu SAS (SAS, 1999) korištenjem MIXED procedure. Podaci o prinosu ST utvrđeni su korištenjem jednosmjerne analize varijance (ANOVA) s tretmanom kao izvorom varijabiliteta. Podatci o hranidbenoj vrijednosti silirane biljne mase utvrđeni su po metodi slučajnog bloknog rasporeda te njihovom interakcijom kao izvorima varijabiliteta.

\section{REZULTATI ISTRAŽIVANJA I RASPRAVA REZULTATA}

$U$ istraživanju je uspoređeno nekoliko gospodarskih svojstava dvaju hibrida sudanske trave SuSu i Pacific graze. Praćeni parametri su važni za stočarsku proizvodnju jer govore o prinosu krme po jedinici površine, te koncentraciji hranjivih tvari po jedinici suhe tvari (ST) čime se može procijeniti potencijal za proizvodnost životinja.

U tablici 1 je prikazan broj biljaka sudanske trave na 2 m duljine u slučajno odabranom redu.

Tablica 1. Broj biljaka sudanske trave na $2 \mathrm{~m}$ duljine

Table 1 Number of plants of Sudan grass at $2 \mathrm{~m}$ in length

\begin{tabular}{||c|c|c|c||}
\hline $\begin{array}{c}\text { Sorta sudanske trave/ } \\
\text { Sudan grass variety }\end{array}$ & $\begin{array}{c}\text { Prosjek/ } \\
\text { average }\end{array}$ & Min. & Max. \\
\hline Su-su & 44,67 & 32 & 55 \\
\hline Pacific graze & 41,33 & 29 & 56 \\
\hline
\end{tabular}

Min-minimalni broj biljaka; Max-maksimalni broj biljaka,

Min, minimal number of plants, Max, maximal number of plants

Broj biljaka sudanske trave na 2 m duljine je $u$ prosjeku bio veći kod sorte Su-su u usporedbi sa sortom Pacific. Gustoća sklopa usjeva sudanske trave je u prosjeku iznosila 93.000 biljaka ha-1 (sorta Pacific graze) i 100.000 biljaka ha-1 (sorta Su-su). Gustoća sklopa je ovisna o namjeni usjeva te primijenjenoj agrotehnici uzgoja (Stipešević i sur., 2019.). 
Povećanje gustoće sklopa povećava prinos ST (Lauer, 1998.), ali i kompeticiju između biljka za vodu, svjetlo i hranjive tvari što može smanjiti prinos samo pojedinih biljka bez negativnog utjecaja na prinos usjeva (Thomas i sur., 2001).

U tablici 2 je prikazan kemijski sastav svježe biljne mase sudanske trave prije siliranja te $\mathrm{pH}$ vrijednost svježe i silirane biljne mase. U ovom istraživanju je usjev sudanske trave korišten za potrebe istraživanja pri prosječnoj visini biljaka od $110 \mathrm{~cm}$ što se uklapa u preporuke košnje usjeva sudanske trave kod visine biljaka od $100-120 \mathrm{~cm}$ kada se postiže visoki prinos i visoka hranidbena vrijednost proizvedene krme za hranidbu životinja (Miron i sur., 2006.).

Sadržaj suhe tvari usjeva za siliranje utječe na sve fizikalne, biološke i kemijske procese u silosu. Ovisno o vrsti usjeva i primijenjenoj tehnologiji, biljna se masa može provenuti na određenu razinu suhe tvari ili se može silirati direktno, bez provenjavanja (Vranić i sur., 2018.; Scherer i sur., 2019.). Krma niskog sadržaja suhe tvari lakše se zbija u silosu u odnosu na krmu visokog sadržaja suhe tvari, ali u cilju proizvodnje silaže visoke hranidbene vrijednosti i osiguranja optimalne zbijenosti u silosu, krmu je preporučljivo djelomično provenuti čime se povećava koncentracija supstrata za fermentaciju (vodotopivi šećeri), sprječavaju ili smanjuju gubitci hranjivih tvari otpuštanjem silažnog soka iz silosa, a krmu je moguće čvrsto zbiti u silosu (Vranić i sur., 2018.; Steinwidder i sur., 2003.). U ovom je istraživanju biljna sudanska trava silirana izravno bez provenjavanja, pa je sadržaj ST hibrida Su-su varirao od $128,8 \mathrm{~g} \mathrm{~kg}^{-1}$ do $159,5 \mathrm{~g} \mathrm{~kg}^{-1}$ svježe biljne mase, a sadržaj ST hibrida Pacific od $132,9 \mathrm{~g} \mathrm{~kg}^{-1}$ do $164,8 \mathrm{~g} \mathrm{~kg}^{-1}$ svježe biljne mase. Usporedbom $\mathrm{pH}$ vrijednost svježe biljne mase i pH vrijednosti silirane biljne mase nakon 35 dana od zatvaranja silosa, vidljivo je prosječno sniženje $\mathrm{pH}$ vrijednosti sorte Su-su do $\mathrm{pH} 4,44$, odnosno sorte Pacific do pH 4,33. Sudanska trava je pogodna za siliranje zbog visokog udjela šećera u ST te niskog pufernog kapaciteta biljnog materijala (Budak i Aydemir, 2017.) što je ovim istraživanjem potvrđeno. Optimalna $\mathrm{pH}$ vrijednost travne silaže je 3,9-4,4 (Phillips i sur., 1981.) unutar kojih raspona se nalaze utvrđene prosječne $\mathrm{pH}$ vrijednosti fermentirane krme sudanske trave. Siliranjem biljne mase mora se postići određena razina kiselosti kako bi se izbjegla nepoželjna fer- mentacija u silosu te razvoj bakterija truljenja i plijesni koje negativno utječu na hranidbenu vrijednost fermentirane krme i zdravlje stada (Phillips i sur., 1981.).

U tablici 3 prikazani su parametri prinosa ST i hranidbene vrijednosti fermentirane krme sudanske trave.

Iz tablice 3 je vidljiv prosječni prinos ST sudanske trave hibrida Su-su od 12,88 $\mathrm{t} \mathrm{ha}^{-1}$, a prinos ST sudanske trave sorte Pacific $11,5 \mathrm{t} \mathrm{ha}^{-1}$, ali nisu utvrđene statistički značajne razlike između istraživanih sorata sudanske trave u prinosu krme po jedinici površine. U ranijim istraživanjima utvrđen je prinos zelene biljne mase različitih hibrida sudanske trave od 40-50 t svježe biljne mase ha ${ }^{-1}$ koji iznosi 9-12 t ST ha-1 (Ibrahim i sur., 2016.) te su u skladu $s$ utvrđenim prinosom ST sudanske trave u ovom istraživanju. Utvrđen prinos svježe biljne mase sudanske trave od $97 \mathrm{t} \mathrm{ha}^{-1}$, odnosno oko $19 \mathrm{t} \mathrm{ST} \mathrm{ha-1}$ (Uzun i sur., 2009.) veći je od utvrđenog u ovom istraživanju.

Utvrđen je prosječan sadržaj SP hibrida Su-su $103,8 \mathrm{~g} \mathrm{~kg}^{-1}$ ST, a hibrida Pacific $102,3 \mathrm{~g} \mathrm{~kg}^{-1}$ ST. U ranijim istraživanjima je utvrđen približno jednak sadržaj SP sudanske trave koji je iznosio $100 \mathrm{~g} \mathrm{~kg}^{-1}$ ST (Vranić i sur., 2014.), 100,7 g kg-1 ST (Uzun i sur., 2009.) ili nešto veći sadržaj SP kod korištenja usjeva sudanske trave za napasivanje na prosječnoj visini biljaka od 50-75 cm (113,3 g SP kg-1 ST) (Parlak i sur., 2016.). Utvrđeni sadržaj SP sudanske trave u ovom istraživanju uklapa se u raspon sadržaja SP silirane sudanske trave od 87-109 g SP kg-1 ST (Wedig i sur., 1987.; Marsalis i sur., 2010.).

Sadržaj NDV, indikatora energetskog potencijala krme koji se koristi u regresivnim jednadžbama za izračun energije krmiva, iznosio je $507 \mathrm{~g} \mathrm{~kg}^{-1}$ ST kod sorte Pacific, odnosno $514 \mathrm{~g} \mathrm{~kg}^{-1}$ ST kod sorte Susu. U ranijem istraživanju je utvrđen viši sadržaj NDV sudanske trave koji je iznosio $611 \mathrm{~g} \mathrm{NDV} \mathrm{kg}^{-1} \mathrm{ST}$ (Parlak i sur., 2016.). U ovom istraživanju je utvrđen viši sadržaj KDV u usporedbi s $315,8 \mathrm{~g} \mathrm{~kg}^{-1}$ ST u istraživanju hranidbene vrijednosti sudanske trave korištene za napasivanje (Parlak i sur., 2016.).

Između dva hibrida sudanske trave korištena u ovom istraživanju nisu utvrđene statistički značajne razlike u hranidbenoj vrijednosti fermentirane krme niti u kvaliteti fermentacije u silosu. 
Tablica 2. Kemijski sastav sudanske trave prije siliranja ( $\mathrm{g} \mathrm{kg}^{-1} \mathrm{ST}$ ako nije drugačije navedeno) Table 2 Sudan grass chemical composition prior ensiling ( $\mathbf{g ~ k g}^{-1} \mathrm{DM}$ unless otherwise stated)

\begin{tabular}{||l|c|c|c|c|c|c||}
\hline $\begin{array}{c}\text { Parametri } \\
\text { Parameters }\end{array}$ & $\begin{array}{c}\text { ST / } \\
\text { DM }\end{array}$ & $\begin{array}{c}\text { SP } \\
\text { CP }\end{array}$ & $\begin{array}{c}\text { NDV } \\
\text { NDF }\end{array}$ & $\begin{array}{c}\text { KDV } \\
\text { ADF }\end{array}$ & $\begin{array}{c}\text { pH } \\
\text { svježe fresh }\end{array}$ & $\begin{array}{c}\text { pH } \\
\text { silirano ensiled }\end{array}$ \\
\hline \multicolumn{7}{|c|}{ Pacific } \\
\hline Prosjek/average & 144,8 & 102,3 & 507 & 326 & 6,11 & 4,33 \\
\hline Min. & 132,9 & 85 & 475 & 298 & 6,1 & 4,26 \\
\hline Max. & 164,8 & 117 & 531 & 354 & 6,15 & 4,43 \\
\hline \multicolumn{7}{|c|}{ Su-su } \\
\hline Prosjek/Average & 142,7 & 109,8 & 514,5 & 326,8 & 6,05 & 4,44 \\
\hline Min. & 128,8 & 86 & 494 & 306 & 6,01 & 4,1 \\
\hline Max. & 159,5 & 126 & 544 & 356 & 6,95 & 4,79 \\
\hline
\end{tabular}

ST, suha tvar (u g kg-1 svježeg uzorka); SP,sirovi proteini; NDV, neutralna detergent vlakna; KDV, kisela detergent vlakna, Min., minimalna vrijednost; Max., maksimalna vrijednost.

DM, dry matter (in $\mathrm{g} \mathrm{kg}^{-1}$ fresh sample); CP, crude protein; NDF, neutral detergent fibre; ADF, acid detergent fibre; Min., minumum value; Max., maximal value.

Tablica 3. Hranidbena vrijednost dvije sorte fermentirane krme sudanske trave (u g $\mathbf{~ g g}^{-1}$ ST ako nije drugačije navedeno)

Table 3 Feeding value of two fermented Sudan grass varieties (in $\mathbf{~ g ~ k g}^{-1}$ DM unless otherwise stated)

\begin{tabular}{|c|c|c|c|c|}
\hline \multirow{2}{*}{$\begin{array}{l}\text { Kemijski parametar } \\
\text { Chemical parameter }\end{array}$} & \multicolumn{2}{|c|}{ Sorte/varieties } & \multirow{2}{*}{ SEM } & \multirow{2}{*}{$P$} \\
\hline & Pacific graze & Su-su & & \\
\hline PST/DMY (t ha-1) & 11,5 & 12,88 & 1,13 & 0.4094 \\
\hline ST /DM & 144,7 & 142,7 & 7,6 & 0.7721 \\
\hline KST/CDM & 150,8 & 148,1 & 5,3 & 0.7155 \\
\hline OT/OM & 956 & 960 & 0,58 & 0.8123 \\
\hline $\mathrm{SP} / \mathrm{CP}$ & 102,3 & 103,8 & 5,4 & 0.3488 \\
\hline NDV/NDF & 507 & 514 & 8,01 & 0.5232 \\
\hline KDV/ADF & 326 & 326,8 & 8 & 0.9432 \\
\hline ME (MJ kg-1 ST/DM) & 9,6 & 9,6 & 0,2 & 0.3409 \\
\hline $\mathrm{pH}$ & 4,26 & 4,4 & 0,08 & 0.2544 \\
\hline $\begin{array}{l}\mathrm{NH}_{3}-\mathrm{N} \\
\left(\mathrm{g} \mathrm{N} \mathrm{kg} \text { kg }^{-1} \text { ukupnog/total N) }\right.\end{array}$ & 116,1 & 131,1 & 24,3 & 0.1933 \\
\hline FME/ME & 0,67 & 0,67 & 0,008 & 0.6821 \\
\hline D-vrijednost/value (\%) & 60,5 & 60,2 & 0,9 & 0.8021 \\
\hline RSP/DCP & 0,845 & 0,85 & 0,005 & 0.3951 \\
\hline $\begin{array}{l}\text { Faktor konzumacije (goveda)/ } \\
\text { Intake factor cattle }\end{array}$ & 70,5 & 70,1 & 0,26 & 0.4010 \\
\hline $\begin{array}{l}\text { Faktor konzumacije (ovce)/ } \\
\text { Intake factor sheep }\end{array}$ & 63,6 & 60,5 & 2,03 & 0.4692 \\
\hline
\end{tabular}

PST- prinos suhe tvari; ST- suha tvar ( $\mathrm{u} \mathrm{g} \mathrm{kg}^{-1}$ svježe biljne mase); $\mathrm{NH}_{3}-\mathrm{N}$, amonijski $\mathrm{N}$ u ukupnom dušiku; KST, suha tvar korigirana za hlapive komponente; ME, metabolička energija; D vrijednost, probavljiva organska tvari u suhoj tvari; SP, sirovi proteini; FME/ME, fermentirajuća metabolička energija u metaboličkoj energiji (energija dostupna za mikrobe buraga); OT, organska tvar; RSP- razgradivi sirovi protein; NDV- neutralna detergent vlaknina; KDV, kisela detergent vlaknina; $P$, stupanj signifikantnosti; NS- nije signifikantno $(P>0,05)$, SEM - standardna pogreška aritmetičke sredine.

DMY, dry matter yield; DM, dry matter (in $\mathrm{g} \mathrm{kg}^{-1}$ fresh forage); $\mathrm{NH}_{3}-\mathrm{N}$, ammonia $\mathrm{N}$ in total $\mathrm{N}$; CDM, corrected DM for volatiles; ME, metabolic energy; $\mathrm{D}$-value, digestible organic matter in the dry matter; CP, crude protein; FME/ME, fermented metabolic energy in the metabolic energy (energy available for rumen microorganisms); OM, organic matter; DCP, degradable CP; NDF, neutral detergent fibre; ADF, acid detergent fibre; $\mathrm{P}$, degree of significance; NS, not significant $(P>0.05)$, SEM - standard error of arithmetic mean. 
Sadržaj $\mathrm{NH}_{3}-\mathrm{N}$ u silaži dobre kvalitete može iznositi do $50 \mathrm{~g} \mathrm{NH}_{3}-\mathrm{N} \mathrm{kg}^{-1}$ ukupnog $\mathrm{N}$ (Chamberlain i Wilkinson, 1996.) Rezultati dobiveni u ovom istraživanju pokazuju veće vrijednosti od poželjnih za sadržaj NH3-N i upućuju na zaključak da prilikom siliranja anaerobni uvjeti u silosu nisu postignuti dovoljno brzo, da travna masa nije dovoljno sabijena (visok sadržaj ST) i/ili da su analizirani uzorci travne silaže uglavnom bili podvrgnuti naknadnoj fermentaciji nakon otvaranja silosa (Chamberlain i Wilkinson, 1996.). Silaža bi trebala sadržavati minimalno 11 MJ ME kg-1ST (Chamberlain i Wilkinson, 1996.), a u ovom istraživanju su vrijednosti sadržaja ME iznosile 9,6 $\mathrm{MJ} \mathrm{kg}^{-1} \mathrm{ST}$.

$\mathrm{U}$ analiziranim uzorcima vrijednost $\mathrm{pH}$ je iznosila 4,26 odnosno 4,4 za sortu Pacific graze i Su-su tim redoslijedom. Siliranjem biljne mase mora se postići kritična razina kiselosti, kako bi se izbjegla nepoželjna fermentacija (razvoj bakterija maslačno kiselinskog vrenja, bakterija truljenja, plijesni) (Thomas i Fisher, 1991.). Osim pufkernog kapaciteta biljke i sadržaja ugljikohidrata topivih u vodi (UTV), $\mathrm{pH}$ vrijednost silaže ovisi i o sadržaju ST, pa u travnoj silaži izvrsne kvalitete može varirati od 3,8 kada je sadržaj ST $15 \%$, pa do 5,5 ili 5,8 kod sadržaja ST $30-40 \%$. Ovo potvrđuju rezultati istraživanja u kojima je travna silaža visoke kvalitete imala relativno visok $\mathrm{pH}(5,0)$ zbog visokog sadržaja ST biljne mase za siliranje $(51,4 \%)$ (Gordon i Murdoch, 1978.)

Probavljivost organske tvari u suhoj tvari (Dvrijednost) je iznosila $605 \mathrm{~g} \mathrm{~kg}^{-1}$ za sortu Pacific graze, odnosno $602 \mathrm{~g} \mathrm{~kg}^{-1}$ za sortu Su-su, što je niže od rezultata probavljivosti sudanske trave od $672,7 \mathrm{~g} \mathrm{~kg}^{-1}$ (Parlak i sur., 2016.). Faktor konzumacije za goveda ili ovce govori o potencijalnoj konzumaciji krme od strane goveda ili ovaca. Faktor konzumacije kvalitetne krme trebao bi iznositi više od 125. U ovom istraživanju oba hibrida sudanske trave preferiraju goveda u odnosu na ovce, a nizak faktor konzumacije za obje sorte i za obje vrste životinja ukazuje na krmu niže hranidbene vrijednosti. Od brojnih čimbenika koji utječu na hranidbenu vrijednost voluminozne krme, najznačajniji utjecaj ima fitofenološka zrelost tratine u trenutku košnje ili korištenja, odnosno rok košnje biljne mase (Alstrup i sur., 2016.). U cilju proizvodnje voluminozne krme visoke hranidbene vrijednosti, što je osnova nekih stočarskih proizvodnji, poput proizvodnje mlijeka, travnjak se preporuča kositi u ranijim stadijima rasta biljaka koji osiguravaju optimalan prinos krme po jedinici površine i optimalnu hranidbenu vrijednost (Akdeniz i sur., 2019.). Ranijom košnjom tratine osigurava se kvaliteta, a kasnijom prinos krme po jedinici površine.

\section{ZAKLJUČAK}

Sudanska trava osigurava visoki prinos krme po jedinici površine, što je potvrđeno ovim istraživanjem. Fermentirana voluminozna krma dvaju hibrida sudanske trave korištena u ovom istraživanju je bila osrednje do niske hranidbene vrijednosti za hranidbu ovaca i goveda čemu govori u prilog niži sadržaj metaboličke energije i sirovih proteina, a visok neutralnih $i$ kiselih detergent vlakana radi kasnijeg roka košnje krme za siliranje. Između dva hibrida sudanske trave korištena u ovom istraživanju nisu utvrđene statistički značajne razlike u prinosu krme po jedinici površine, u hranidbenoj vrijednosti fermentirane krme niti u kvaliteti fermentacije $u$ silosu.

\section{LITERATURA}

1. Afzal M., Ahmad A., Ahmad A. H. (2012.): Effect of nitrogen on growth and yield of sorghum forage (Sorghum bicolor ( L.) Moench cv.) under three cuttings system. Cercetari Agronomice in Moldova, 45, 4: 57-64.

2. Akdeniz H., Hosaflioglu I., Koc A., Hossain A., Islam M.S., Iqbal M.A., Imtiaz H.,

3. Gharib H., El Sabagh A. (2019.): Evaluation of Herbage Yield and Nutritive Value of

4. Eight Forage Crop Species. Applied Ecology and Environmental Research 17:5571

5. 5581 .

6. Alstrup L., Soegaard K., Weisbjerg M.R. (2016.): Effects of maturity and harvest

7. season of grass-clover silage and of forage-to-concentrate ratio on milk production of

8. dairy cows. Journal of Dairy Science 99:328-340.

9. AOAC (1990.): Official methods of the association of analytical chemists. Vol. 2, 15th Edition. AOAC, Arlington, Virginia, USA. 
10. Budak F., Aydemir, S. K. (2017.): Determination and Comparison of Yield and Yield Components of Sorghum (Sorghum Bicolor L.), Sudan Grasses (Sorghum Sudanense L.), Sorghum Sudangrass Hybrids (Sorghum Bicolor X Sorghum Bicolor Var. Sudanense) and Corn (Zea Mays L.) Varieties Grown as a Second Crop on Western Transition Zone after Hungarian Vetch (Vicia Pannonica Crantz). Fresenius Environmental Bulletin, 26, 8: 5153-5162.

11. Chamberlain A.T., Wilkinson J.M. (1996.): Feeding the Dairy Cow. Chalcombe Publications, PainShall, Ln2 3LT, UK.

12. Cleale R.M., Bull L.S. (1986.): Effect of Forage Maturity on Ration Digestibility and Production by DairyCows. Journal of Dairy Science 69:1587-1594.

13. Erić P., Ćupina B., Mihailović V., Pataki I. (1999.): Specifičnosti tehnologije proizvodnje krmnog sirka i sudanske trave pri različitim načinima njihovog korišćenja. Zbornik Radova Instituta za ratarstvo i povrtarstvo, 3, 225-223.

14. Gordon F.J., Murdoch J.C. (1978.): An evaluation of a high-quality grass silage for milk production, Journal of the British Grassland Society, Volume 33, 5-11.

15. Ibrahim A. M., Zeidan E. M. I., Geweifel H. G. M., Abd El-Hameed I. M., Mahfouz S.A. (2016.): Influence of planting density and nitrogen fertilizer levels on fresh forage yield and quality of some forage sorghum genotypes. Zagazig Journal of Agricultural Research, 43, 3: 729-743.

16. Kralik D., Elter A., M., Kukić S., Uranjek N., Spajić R. (2009.): Sudanska trava - energetska biljka za proizvodnju bioplina, Krmiva 51, 3: 171-178.

17. Lauer J.G. (1998.): Corn silage yield and quality trade-offs when changing Culling height. Field Crops, 28:47-18.

18. Marsalis M.A., Angadi S.V., Contreras-Govea F.E. (2010.): Dry matter yield and nutritive value of corn, forage sorghum, and BMR forage sorghum at different plant populations and nitrogen rates. Field Crops Research, 116, 52-57.

19. McLaren J.S., Lakey N., Osborne J. (2003.): Sorghum as a bioresources platform for future renewable resources. Proceedings $57^{\text {th }}$ Corn and Sorghum Research Conference. CD ROM. American Seed Trade Association, Alexandria, Virginia.

20. Miron J., Solomon R., Adin G., Nir U., Nikbachat M., Yosef E., Carmi A., Weinberg Z.G., Kipnis T., Zuckerman E., Ben-Ghedalia D. (2006.): Effects of harvest stage and re-growth on yield, composition, ensilage and in vitro digestibility of new forage sorghum varieties. Journal of Science of Food in Agriculture, 86, 140-147.
21. Niderkorn V., Baumont R. (2009.): Associative effects between forages on feed intake and digestion in ruminants. Animal 3:951-960.

22. Parlak A.O., Gokkus A., Alaturk F., Hanoglu H., Tolu C. (2016.): Herbage yield and quality of wheat stubble and sorghum sudan-grass pastures. Scientific papers series A-agronomy, 59, 374-377.

23. Phillips W.A., Pendlum L.C., Horn F.P. (1981.): Ensiling of Whole Wheat Plant at Different Maturities and Dry-Matter. Oklahoma Agricultural Experiment Station Miscellaneous Publication, 106-107.

24. SAS (1999.): SAS ${ }^{\circledR}$ Software. SAS Institute Inc. Cary, North Carolina, USA

25. Scherer R., Gerlach K., Taubert J., Adolph S., Weiss K., Sudekum K.H. (2019.): Effect of forage species and ensiling conditions on silage composition and quality and the feed choice behaviour of goats. Grass and Forage Science, 74, 297-313.

26. Stipešević B., Brozović B., Jug D., Jug I., Vukadinović V., Đurđević B. (2019.): Effects of tillage method and fertilizer type on the yield of Sudan grass (Sorghum bicolor L.). Turkish Journal of Agriculture and Forestry, 43, 3778-387.

27. Stjepanović M., Gantner R., Bagarić H., Radan Z., Marincel I., Koričić Z. (2011.): Prinos zelene mase i korištenje sudanske trave kod naknadne sjetve, Proceedings. $46^{\text {th }}$ Croatian and $6^{\text {th }}$ International Symposium on Agriculture. Opatija. Croatia, 732-735.

28. Steinwidder A., Zeiler E., Guggenberger T., Hausler J., Schauer A., Gruber L. (2003.): Effect of particle size and dry matter content of grass silage at different concentrate levels on ruminal fermentation patterns, digestibility and feed intake of cattle - $1^{\text {st }}$ communication: Experimental methods and results concerning the feed quality as well as the investigations with ruminally fistulated cattle. Zuchtungskunde, 75,176189.

29. Thomas C., Fisher G. (1991.): Forage conservation and winter feeding. In Thomas, C., Reeve, A., Fisher, G.E.J. (eds.) Milk from Grass. ICI, SAC, IGER, 2nd edn. 27-51. British Grassland Society, Reading.

30. Thomas E.D., P. Mandebvu, C.S. Ballard, C.J. Sniffen, M.P. Carter, J. Beck (2001.). Comparison of corn silage hybrids for yield, nutrient composition, in vitro digestibility, and milk yield by dairy cows. Journal of Dairy Science, 84, 2217-2226.

31. Uzun F., Ugur S., Sulak M. (2009.): Yield, Nutritional and Chemical Properties of Some Sorghum x Sudan Grass Hybrids (Sorghum bicolour (L.) Moench x Sorghum sudanense Stapf.). Journal of Animal and Veterinary Advances, 8, 1602-1608. 
32. Vranić M., Bošnjak K., Kvesić B., Čačić I. (2014.): Utjecaj visine košnje na prinos suhe tvari i hranjivosti silaže hibrida sirka i sudanske trave. $49^{\text {th }}$ Croatian and $9^{\text {th }}$ International Symposium on Agriculture. Dubrovnik. Croatia, 434-438.

33. Vranić M., Bošnjak K., Lukšić B., Čačić I., Šebalj G. (2018.): Utjecaj duljine provenjavanja na hranidbenu vrijednost fermentirane krme poluprirodnog travnjaka. Krmiva : časopis o hranidbi životinja, proizvodnji i tehnologiji krme, 60, 1: 43-50.

34. Vranić M.; Bošnjak K.; Glavanović, S.; Pintić Pukec N.; Babić A.; Vranić I. (2019.a): Procjena ad libitum konzumacije i in vivo probavljivosti voluminozne krme NIR spektroskopijom. Krmiva : časopis o hranidbi životinja, proizvodnji i tehnologiji krme, 61, 2: 67-75.
35. Vranić M.; Bošnjak K.; Glavanović, S.; Mašek T. (2019.b): Razvoj kalibracija za procjenu hranidbene vrijednosti voluminozne krme bliskom infracrvenom (NIR) spektroskopijom. Krmiva : časopis o hranidbi životinja, proizvodnji i tehnologiji krme, 61, 2: 93-101.

36. Vranić M.; Bošnjak K.; Rukavina, I.; Glavanović, S. Pintić Pukec N.; Babić A.; Vranić I. (2020.): Procjena kemijskog sastava voluminozne krme NIR spektroskopijom. Journal of Central European agriculture, 21, 3: 554-568.

37. Wedig C.L., Jaster E.H., Moore K.J., Merchen N.R. (1987.): Rumen turnover and digestion of normal and brown midrib sorghum $\times$ sudangrass hybrid silages in dairy cattle. Journal of Dairy Science, 70, 11201127.

\section{SUMMARY}

The objective of the paper was to compare the feeding value of two fermented hybrids of Sudan grass with regard to forage yield, chemical composition and fermentation in the silo. Two varieties of sudan grass, the Su-Su variety and the Pacific graze variety were used in the study. The research was conducted during the growing season in 2014 on the experimental plot of the University of Zagreb Faculty of Agriculture.

The harvested forage was ensiled into laboratory silo. After 35 days of ensiling, the fermented forage was analyzed by NIR spectroscopy on the chemical composition and the fermentation quality, and there were estimated forage organic matter $(\mathrm{OM})$, crude protein (CP), neutral detergent fiber (NDF) and acidic detergent fiber (ADF) content, and metabolic energy (ME), digestibility of the organic matter in the dry matter (D-value), crude protein degradability (CPD), intake factor for sheep and cattle, $\mathrm{pH}$ value and ammonia $\mathrm{N}\left(\mathrm{NH}_{3}-\mathrm{N}\right)$. No statistically significant differences were determined between Pacific Graze and Su-su hybrids in the investigated parameters. The DM yield of hybrids Pacific graze and Su-su was $11.5 \mathrm{tha}^{-1}$ and $12.88 \mathrm{t} \mathrm{ha}^{-1}$ respectively $(\mathrm{P}>0.409), \mathrm{CP}$ content $102.3 \mathrm{~g} \mathrm{~kg}^{-1} \mathrm{DM}$ and $103.8 \mathrm{~g} \mathrm{~kg}^{-1} \mathrm{DM}$ respectively ( $P>0.802)$, NDF content $507 \mathrm{~g} \mathrm{~kg}^{-1} \mathrm{DM}$ and $514 \mathrm{~g} \mathrm{~kg}^{-1} \mathrm{DM}$ respectively $(P>0.523)$, D-value $605 \mathrm{~g} \mathrm{~kg}^{-1} \mathrm{DM}$ and $602 \mathrm{~g} \mathrm{~kg}^{-1} \mathrm{DM}$ respectively $(\mathrm{P}>0.341), \mathrm{pH}$ 4.26 and 4.4 respectively $(P>0.193)$, and $\mathrm{NH}_{3}-\mathrm{N}^{-1}$ content $116 \mathrm{~g} \mathrm{NH}_{3} \mathrm{~kg}^{-1}$ total $\mathrm{N}$ and $131 \mathrm{~g} \mathrm{NH}^{3} \mathrm{~kg}^{-1}$ total $\mathrm{N}$ respectively $(\mathrm{P}>0.254)$. It was concluded that both Sudan grass hybrids have the potential to produce high-yield fermented forage per unit area while the lower nutritive value of fermented forage in this study was a result of advanced Sudan grass maturity at harvest.

Keywords: Sudan grass, varieties, nutrition value, fermentation quality 